\title{
Jurist-Diction
}

Volume 1 No. 2, November 2018

Article history: Submitted 1 October 2018; Accepted 8 October 2018; Available online 1 November 2018

\section{SURAT PERINTAH KERJA (SPK) SEBAGAI OBJEK JAMINAN KREDIT}

\author{
Bima Ade Wiyatno \\ bimaadew@gmail.com \\ Universitas Airlangga
}

\begin{abstract}
The Work Order (SPK) has the same use as the work contract, which is to show the relationship between the user and the service provider. With the existence of a Work Order (SPK) or employment contract, this will lead to the right to claim service providers to service users for a payment if the project's work has been completed. This claim right is identical to the receivable in the name because the one who can collect is the person whose name is listed in the Work Order (SPK). The claim rights that are born from the Work Order (SPK) can be used as the main guarantee in applying for credit to the bank whose binding is done cessie or by affirming the transfer of project terms accompanied by a letter of participation. In addition to the main guarantee in the form of a Work Order (SPK) which gives birth to the claim right, there is also an additional guarantee. Additional guarantees are used to pay off debts from service providers to banks if the main guarantee cannot be used to repay the debt. The existence of the main guarantee in the form of claim rights plus additional collateral required by the bank causes the position of the bank as a preverent creditor. If the debtor is unable to fulfill his achievements as agreed so as to cause a default. Default can occur due to intentional or accidental actions. When a default occurs, the bank will try to keep the service provider able to complete the project so that the debtor's debt repayment can be settled through the transfer of claim rights born from the Work Order (SPK) between the service provider and the service user. If all has been done by the bank but the service provider still cannot complete the project so that the repayment of the debt with a Work Order (SPK) cannot be carried out then the repayment of the debtor's debt is carried out by executing an additional guarantee.
\end{abstract}

Keywords: Work Order (SPK); Guarante; Bank Position.

\begin{abstract}
Abstrak
Surat Perintah Kerja (SPK) mempunyai kegunaan yang sama dengan kontrak kerja yaitu untuk menunjukkan adanya hubungan antara pihak pengguna dan penyedia jasa. Dengan adanya Surat Perintah Kerja (SPK) atau kontrak kerja inilah yang nantinya akan menimbulkan suatu hak tagih penyedia jasa kepada pengguna jasa atas suatu pembayaran jika pengerjaan proyeknya telah selesai. Hak tagih ini identik dengan piutang atas nama karena yang dapat menagih adalah orang yang namanya tercantum dalam Surat Perintah Kerja (SPK). Hak tagih yang lahir dari Surat Perintah Kerja (SPK) ini dapat dijadikan sebagai jaminan utama dalam pemohonan kredit kepada bank yang pengikatannya dilakukan secara cessie atau dengan penegasan pelimpahan termijn proyek yang disertai dengan surat penyertaan. Selain jaminan utama yang berupa Surat Perintah Kerja (SPK) yang melahirkan hak tagih, terdapat juga jaminan tambahan. Jaminan tambahan digunakan untuk melunasi utang dari penyedia jasa kepada bank jika jaminan utama tidak dapat digunakan untuk melunasi utang tersebut. Adanya jaminan utama yang berupa hak tagih ditambah dengan jaminan tambahan yang dipersyaratkan oleh pihak bank menyebabkan kedudukan pihak bank sebagai kreditur preverent. Apabila debitor tidak bisa memenuhi prestasinya sebagaimana yang telah diperjanjikan sehingga menyebabkan terjadinya wanprestasi. Wanprestasi dapat terjadi karena perbuatan yang disengaja maupun tidak sengaja. Ketika wanprestasi terjadi maka pihak bank akan berusaha agar penyedia jasa tetap dapat menyelesaikan proyeknya sehingga pelunasan utang debitor dapat diselesaikan melalui pengalihan hak tagih yang lahir dari Surat Perintah Kerja (SPK)
\end{abstract}


antara penyedia jasa dengan pengguna jasa . Apabila semua sudah dilakukan oleh pihak bank tetapi pihak penyedia jasa tetap tidak dapat menyelesaikan proyeknya sehingga pelunasan utang dengan Surat Perintah Kerja (SPK) tidak dapat terlaksana maka pelunasan utang debitor dilakukan dengan mengeksekusi jaminan tambahan.

Kata Kunci: Surat Perintah Kerja (SPK); Jaminan; Kedudukan Bank.

\section{Pendahuluan}

Pembangunan infrasturuktur di Indonesia semakin membaik. Hal ini dibuktikan oleh indeks daya saing infrastruktur Indonesia tahun 2018 berada di peringkat 52, yang sebelumnya pada tahun 2012-2013 berada diperingkat 78 dari 137 negara. ${ }^{1}$ Infrastruktur yang handal merupakan kunci utama dalam meningkatkan daya saing Indonesia. Namun masih ada permasalahan yang harus dihadapi oleh Indonesia dalam melakukan pembangunan infrastruktur, mulai dari disparitas wilayah dan pemanfaatan sumber daya manusia dan alam. Oleh karena itu, infrastruktur harus ditempatkan sebagai prioritas kebijakan pembangunan nasional, tujuannya adalah untuk mempercepat pertumbuhan ekonomi di Indonesia. Adanya kualitas dan ketersediaan infrastruktur yang memadai, daya saing Indonesia semakin membaik. Hal ini menyebabkan Indonesia masuk kedalam daftar layak investasi di pasar global. Selain itu, mengingat tujuan negara guna memajukan kesejahteraan umum, maka diperlukan percepatan pembangunan infrastruktur prioritas. Berdasarkan Peraturan Presiden Nomor 122 Tahun 2016 tentang Perubahan Atas Peraturan Presiden Nomor 75 Tahun 2014 tentang Penyediaan Infrastruktur Prioritas. ${ }^{2}$

Indonesia pada saat ini berada dalam perubahan-perubahan yang besar, yang terjadi hampir di semua lini kehidupan bangsa, baik sosial, politik, ekonomi, dan budaya. Sebagai salah satu hasil dari perubahan besar tersebut, adalah kehidupan politik bangsa kita bergeser secara sangat mendasar dari masyarakat yang hidup dalam alam kekuasaan monolitik, kedalam kehidupan masyarakat

\footnotetext{
${ }^{1}$ https://economy.okezone.com/read/2018/04/13/320/1886166/infrastruktur-indonesia-di-peringkat-52-dunia-apa-masalahnya yang diakses pada tanggal 13 Mei 2017

2 Peraturan Presiden Nomor 122 Tahun 2016 tentang Perubahan Atas Peraturan Presiden Nomor 75 Tahun 2014 tentang Percepatan Penyediaan Infrastruktur Prioritas, Lembaran Negara Tahun 2016 Nomor 363
} 
yang jauh lebih berkualitas. ${ }^{3}$ Lebih lagi dari sentralisasi masih yang cukup lama menuju desentralisasi dan otonomi daerah yang sangat luas, sehingga cenderung berlebih dalam mengintepretasikannya.Infrastruktur pembangunan jasa konstruksi menyelenggarakan dan meningkatkan peran masyarakat jasa konstruksi dalam melaksanakan pengembangan jasa konstruksi yang kokoh dan handal, serta iklim usaha yang kondusif, transparan, efisien, beretika profesi dan beretika bisnis adalah misi dalam jasa konstruksi tersebut.

Dewasa ini, kontrak pemerintahan merupakan salah satu jenis kontrak yang berkembang sangat dinamis meskipun belum banyak diatur dalam peraturan perundang-undangan. Termasuk diantaranya adalah kontrak pengadaan (procurement contract) dan kontrak-kontrak lain yang dibuat tidak dalam rangka pengadaan barang dan/atau jasa (non-procurement contract).$^{4}$ Berdasarkan jenisjenis kontrak yang telah dibuat oleh Pemerintah merupakan suatu hal yang rutin dilakukan yang bersumber pada kontrak komersial sekalipun didalam ketentuan kontrak tersebut terkandung elemen publik. Kontrak pengadaan barang dan/atau jasa (procurement contract) dimaksudkan untuk mengadakan barang dan/atau jasa tertentu dengan beban yang ditimbulkan kepada negara. Sedangkan pada kontrak bukan pengadaan barang dan/atau jasa adalah kontrak-kontrak yang merupakan bentuk pelayanan publik dan biasanya memberikan keuntungan (benefit) bagi pemerintah. ${ }^{5}$

Dalam Kontrak Konstruksi, baik yang diselenggarakan oleh pemerintah dan swasta, serta swasta dan swasta tunduk pada beberapa sumber hukum baik

3 Joetata Hadihardaja, Membangun Industri Konstruksi Indonesia Menjadi Kelas Dunia, ejournal.undip.ac.id, Vol 13, No.2, 2005.[11].

4 Y. Sogar Simamora, Prinsip dan Pengaturan Kontrak Pemerintah di Indonesia, Semiloka Pembaharuan Hukum Perdata Indonesia, Fakultas Hukum Universitas Airlangga, Surabaya, 2013, h.1 (selanjutnya disebut Y. Sogar Simamora I)

5 Reifon Cristabella Eventia, Prinsip Hukum Dalam Pembentukan dan Pelaksanaan Kontrak Bangun Guna Serah (Build, Operate, Transfer/BOT), Disertasi, Fakultas Hukum Universitas Airlangga, Surabaya, 2016.[7]. 
yang bersifat peraturan perundang-undangan maupun Lex Mercatoria ${ }^{6}$ yang dapat digunakan sebagai acuan pelaksanaan kontrak konstruksi. Secara nasional, terdapat beberapa aturan pokok mengenai kontrak konstruksi, antara lain: Burgelijk Wetboek (BW), ${ }^{7}$ Undang-Undang Nomor 2 Tahun 2017 tentang Jasa Kontrak Konstruksi ${ }^{8}$ yang selanjutnya disebut sebagai UU JK. Dalam bidang konstruksi, penggunaan istilah kontrak disebabkan oleh nuansa bisnis atau komersial dalam hubungan hukum yang dibentuk diantara para pihak. Kontrak sangat melekat pada transaksi bisnis atau komersial. Hal ini bertujuan agar memberikan kepastian diantara para pihak yang terikat dengan kontrak atas segala hal yang telah diperjanjikan terpenuhi.

Selain sumber hukum yang mengatur secara materiil, salah satu aspek yang paling menunjang dalam kontrak kontruksi adalah keberadaan jaminan fidusia. Jaminan mempunyai fungsi yang amat penting dalam kegiatan ekonomi. Hal ini ditunjukkan dalam rangka pemberian modal.

Adapun syarat-syarat disebut prestasi dalam suatu perikatan, adalah sebagai berikut: ${ }^{9}$

1. Suatu prestasi harus merupakan suatu prestasi tertentu, atau sedikitnya dapat ditentujan jenisnya, tanpa adanya ketentuan sulit untuk menentukan apakah debitor telah memenuhi prestasi atau belum;

2. Prestasi harus dihubungkan dengan suatu kepentingan, karena tanpa adanya kepentingan maka seorang tersebut tidak dapat melakukan tuntutan;

3. Prestasi harus diperbolehkan oleh peraturan perundang-undangan, kesusilaan, dan ketertiban umum.

Prestasi harus mungkin dilaksanakan.

${ }^{6}$ Lex Mercatoria yang lazim juga disebut The New Lex Mercatoria merupakan bentuk harmonisasi hukum perdagangan internasioanl yang berupa kebiasaan internasional, ketentuan internasional (International Legislation), dan Model Hukum (Model Law) yang dirancang oleh badanbadan internasional, diambil dari Y. Sogar Simamora, Hukum Kontrak: Kontrak Pengadaan Barang dan Jasa Pemerintah di Indonesia, Kantor Hukum WINS \& Partners-Laksbang Justitia Surabaya, Surabaya, 2012, h. 18 (selanjutnya disebut Y. Sogar Simamora II)

7 Subekti, Kitab Undang-Undang Hukum Perdata (Burgerlijk Wetboek), Pradnya Paramita, Jakarta, 1981

8 Indonesia, Undang-Undang Nomor 2 Tahun 2017 tentang Jasa Konstruksi, Lembaran Negara Indonesia Tahun 2017 Nomor 11, Tambahan Lembaran Negara Nomor 6018

9 Ibid. 
Dalam pelaksanaan kontrak konstruksi yang melibatkan kontraktor dan pemilik proyek tentunya sangat terkait dengan bentuk imbalan dan/atau jasa dari pengerjaan proyek tersebut yang menjadi hak dari kontraktor. Aspek pembayaran merupakan kewajiban kontraktual dari pemilik proyek untuk membayar jasa kontraktor dan hak kontraktual kontraktor atas pekerjaan yang diberikan oleh pemilik proyek sebagaimana yang tertuang dalam kontrak konstruksi. Besaran pembayaran yang biasa disebut dengan "nilai kontrak" merupakan konsensus yang telah disepakati kedua belah pihak realisasi pekerjaan. Beberapa jenis pembayaran yang dilakukan oleh pemilik proyek kepada kontraktor adalah: ${ }^{10}$

1. Pembayaran uang muka;

2. Sejumlah uang yang disepakati dalam sertifikat pembayaran berkala (interim payment certificate);

3. Sejumlah uang yang disepakati dalam sertifikat pembayaran final;

4. Klaim konstruksi.

Selain sejumlah pembayaran tersebut di atas, yang sering menjadi persoalaan dalam kontrak konstruksi juga meliputi beberapa hal, yaitu:

1. Sumber permbiayaan;

2. Mekanisme pembayaran (sekali/berkala/sesuai permintaan);

3. Prosedur pembayaran;

4. Mata uang yang disepakati dalam pembayaran;

5. Metode pembayara (cek/transfer/letter of credit);

6. Metode pengamanan pembayaran (jaminan).

Surat Perintah Kerja adalah surat yang diberikan oleh pihak atasan atau instansi untuk bawahan atau anggota instansi agar melaksanakan tugas tertentu yang diberikan atasan dimana hal tersebut dilakukan agar memperoleh modal kerja. Pada saat menjaminkan Surat Perintah Kerja kepada kreditor, pihak kreditor dapat menerima dan menolak Surat Perintah Kerja sebagai jaminan untuk modal kerja. Dengan dikeluarkannya SPK atau Kontrak Kerja menimbulkan akibat hukum, yaitu membuat kedua belah pihak terikat untuk menjalankan segala hal yang telah menjadi kesepakatan bersama.

${ }^{10}$ Seng Hansen, Manajemen Kontrak Konstruksi, Jakarta: Kompas Gramedia, 2016.[134]. 


\section{Keabsahan Surat Perintah Kerja sebagai Objek Jaminan}

Penyedia jasa dalam mengerjakan proyek tidak mempunyai dana yang cukup untuk melakukan proses pengerjaan, maka penyedia jasa dapat mengajukan permohonan kredit di Bank untuk proses pengerjaan proyek tersebut. Kredit untuk pengerjaan proyek ini disebut dengan Kredit Modal Kerja Pola Keppres. Kredit Modal Kerja Pola Keppres adalah fasilitas kredit modal kerja kepada Kontraktor untuk menyelesaikan suatu pekerjaan berdasarkan Kontrak Kerja dengan plafon tertentu yang pelunasan kreditnya bersumber dari pembayaran termyn Proyek yang bersangkutan. ${ }^{11}$ Hal ini disebabkan karena sebelum bank menyetujui suatu permohonan kredit, bank akan menjalankan prinsi kehati-hatian yang salah satunya adalah prinsip 5C.

Didalam prinsip 5C terdapat unsur yang terpenting, yaitu Prinsip Capital. Prinsip Capital (Modal)adalah modal awal yang harus dimiliki oleh debitor (penyedia jasa) agar dapat menjalankan pengerjaan proyek tersebut. Nilai proyek merupakan nilai kontrak dikurangi dengan pajak-pajak yang wajib dibayar oleh penyedia jasa dan uang muka pembayaran proyek bila ada. Sedangkan nilai kontrak merupakan besaran nilai atau harga yang disepakati antara pengguna jasa dengan penyedia jasa dalam rangka pengadaan atau penyelesaian proyek yang dicantumkan didalam SPK atau Kontrak Kerja. Bidang Usaha yang dapat dibiayai dengan fasilitas Kredit Modal Kerja Pola Keppres adalah badan usaha yang bergerak di bidang :
a. Jasa Konstruksi;
b. Jasa Pengadaan;
c. Jasa Konsultan;
d. Jasa Lainnya.

Mekanisme pengajuan kredit dari pihak penyedia jasa kepada bank, yaitu sebagai berikut: ${ }^{12}$

a. Adanya permohonan kredit lengkap beserta berkas penyedia jasa;

b. Bank mencari data status kredit debitor diseluruh bank dimana penyedia

\footnotetext{
${ }^{11} \mathrm{http}: / /$ www.bankjatim.co.id/id/bisnis/pinjaman-1/kredit-modal-kerja, diakses pada tanggal 18 Agustus 2018 pukul 17.10 WIB

${ }^{12}$ Sutarno, Aspek-aspek Hukum Perkreditan pada Bank, Alfabeta, Bandung, 2005.[97 - 98].
} 
jasa selaku debitor pernah dan masih mengajukan kredit. Apakah kreditnya memenuhi kolektibilitas yang non performingloan atau performing loan. Hal ini dapat diketahui melalui SID (Sistem Informasi Debitor);

c. Laporan kunjungan untuk melihat jaminan dan usaha, taksasi jaminan, serta tafsiran jaminan;

d. Terjadinya pembahasan apakah kredit tersebut akan diberikan atau tidak kepada penyedia jasa. Keputusan pemberian kredit ini merupakan kewenangan dari kelompok pemutus kredit, setelah diputuskan maka dibuat Surat Pemberitahuan Persetujuan Kredit yang selanjutnya disebut SPPK.

Tahap terakhir dari permohonan kredit adalah tahap perjanjian kredit yang mana penandatanganan perjanjian ini mengikat antara pihak bank dengan pihak penyedia jasa. Perjanjian kredit merupakan salah satu aspek terpenting dalam pemberian kredit, tanpa adanya perjanjian kredit yang ditandatangani oleh bank dan debitor maka tidak ada pemberian kredit. ${ }^{13}$ Dalam perbankan pihak-pihak yang berhubungan dengan transaksi kredit ialah pihak yang memberikan kredit disebut kreditor yaitu bank, sedangkan yang menerima kredit adalah debitor yaitu penyedia jasa. ${ }^{14}$

Tenggang waktu ini disesuaikan dengan jangka waktu pelaksanaan proyek berdasarkan SPK atau kontrak kerja. Kredit dapat diperpanjang dengan ketentuan bahwa :Peraturan Presiden Nomor 16 Tahun 2018 tentang Pengadaan Barang dan Jasa.

1. Perpanjangan kredit untuk proyek yang belum selesai harus ada perpanjangan kontrak atau Addendum kontrak.

2. Perpanjangan kredit untuk proyek yang telah selesai tetapi pembayarannya mengalami penundaan oleh pemberi kerja, maka cukup melampirkan:

a) Berita acara serah terima proyek bahwa proyek telah selesai dan telah diterima oleh pemberi kerja

b) Surat keterangan yang diberikan oleh pemberi kerja yang isinya penundaan pembayaran proyek

\footnotetext{
${ }^{13}$ Sutarno, loc.cit

${ }^{14}$ Ibid.[95].
} 
Keberadaan jaminan yang berupa SPK atau kontrak kerja melahirkan suatu hak kebendaan termasuk dalam perjanjian accessoir yang mengikuti perjanjian pokok yaitu perjanjian kredit di bank.

Selain jaminan pokok terdapat jaminan tambahan untuk mendukung pemberian kredit yang diberikan oleh bank. Jaminan tambahan berupa :

a. Barang tidak bergerak berupa hak atas tanah, bangunan, kapal laut;

b. Barang bergerak berupa kendaraan bermotor, stok barang;

c. Deposito / Giro / Tabungan yang diblokir;

d. Surat berharga.

Pengikatan atas benda-benda tersebut dapat dibebani dengan hak tanggungan, fidusia, gadai atau hipotek di dasarkan pada jenis bendanya. Hak tanggungan berdasarkan Pasal 1 angka 1 Undang-undang Nomor 4 Tahun 1996 tentang Hak Tanggunan atas Tanah beserta benda - benda yang berkaitan dengan tanah (selanjutnya disebut dengan UUHT) adalah:

"Hak jaminan yang dibebankan pada hak atas tanah sebagaimana dimaksud dalam Undang - undang Nomor 5 Tahun 1960 tentang Peraturan Dasar Pokok - pokok Agraria, berikut atau tidak berikut benda - benda lain yang merupakan satu kesatuan dengan tanah itu, untuk pelunasan utang tertentu, yang memberikan kedudukan yang diutamakan kepada kreditor tertentu terhadap kreditor - kreditor lain."

Perumusan hak tanggungan yaitu :

1. Hak jaminan;

2. Atas tanah berikut atau tidak berikut benda - benda lain yang merupakan kesatuan dengan tanah yang bersangkutan;

3. Untuk pelunasan suatu utang;

4. Memberikan kedudukan yang diutamakan. ${ }^{15}$

Pengikatan dengan jaminan fidusia dilakukan terhadap jaminan berupa barang yang bergerak dan barang tidak bergerak yang tidak dapat diikat dengan hak tanggungan. Fidusia adalah pengalihan hak kepemilikan suatu benda atas dasar kepercayaan dengan ketentuan bahwa benda yang hak kepemilikannya dialihkan tersebut tetap dalam penguasaan pemilik benda (Pasal 1 angka 1 Undang - undang Republik Indonesia Nomor 42 Tahun 1999 tentang Jaminan Fidusia yang

${ }^{15}$ J. Satrio, Hukum Jaminan Hak Jaminan Kebendaan, Citra Aditya Bakti, Bandung, 2007 (selanjutnya disingkat J. Satrio I).[300]. 
kemudian disebut dengan UUJF. sebagai agunan bagi pelunasan hutang tertentu, yang memberikan kedudukan yang diutamakan kepada penerima fidusia terhadap kreditor lainnya. Unsur-unsur Fidusia yaitu:

1. Hak jaminan;

Hak jaminan adalah hak - hak yang memberikan kepada kreditor suatu kedudukan yang lebih baik dari para kreditor yang lain. Ketentuan Undangundang Fidusia yang mengatur tentang hak yang diutamakan dan hak yang didahulukan tercantum dalam Pasal 1 angka 2 UUJF dan Pasal 27 UUJF.

2. Benda bergerak;

3. Benda tidak bergerak, khususnya bangunan;

4. Tidak dapat dibebani dengan hak tanggungan;

Bangunan yang dapat dijadikan jaminan fidusia adalah bangunan - bangunan yang tidak terdiri di atas tanah hak milik, hak guna usaha, dan hak pakai atas tanah negara.

5. Sebagai agunan;

6. Untuk pelunasan hutang;

7. Kedudukan yang diutamakan. ${ }^{16}$

Menurut Pasal 3 UUJF menyatakan bahwa jaminan fidusia ini tidak berlaku terhadap :

1. Hak tanggungan yang berkaitan dengan tanah dan bangunan, sepanjang peraturan perundang-undangan yang berlaku menentukan jaminan atas benda-benda tersebut wajib terdaftar;

2. Hipotek atas kapal yang terdaftar dengan isi kotor berukuran 20 (dua puluh) $m^{3}$ atau lebih;

3. Hipotek atas pesawat terbang;

4. Gadai.

Dari penjelasan tersebut, maka dapat disimpulkan objek yang dapat diikat secara fidusia dapat berupa:

a. Pasal 1 angka 4 UUJF menjelaskan tentang barang berwujud maupun tidak terwujud, yang terdaftar maupun tidak terdaftar, yang bergerak maupun tidak bergerak, yang tidak dapat dibebani hak tanggungan atau hipotek;

b. Pasal 9 UUJF menjelaskan tentang benda termasuk piutang baik yang telah ada pada saat jaminan yang diberikan maupun yang diperoleh kemudian;

c. Pasal 10 UUJF menjelaskan tentang hasil dari benda yang menjadi objek jaminan fidusia serta klaim asuransi dalam hal benda yang menjadi objek jaminan fidusia diasuransikan;

d. Pasal 20 UUJF menjelaskan tentang benda persediaan.

${ }^{16}$ J. Satrio I, op.cit..[164]. 
Untuk barang yang bergerak selain diikat oleh jaminan fidusia dapat juga diikat dengan gadai.

\section{Jenis Surat Perintah Kerja}

SPK adalah surat perintah kerja yang digunakan oleh perusahaan manufaktur dalam mengerjakan pesanan pelanggan, sehingga akan terlihat laba rugi per-SPK. Fungsi SPK: ${ }^{17}$

a. Sebagai surat resmi perintah pengerjaan suatu proyek;

b. Sebagai dokumentasi proyek yang sudah dikerjakan;

c. Alat estimasi biaya dan laba proyek tertentu secara historical.

Berdasarkan pengertian tentang Surat Perintah Kerja (SPK) di atas maka kesimpulannya adalah surat yang diberikan oleh pihak atasan atau instansi untuk bawahan atau anggota instansi agar melaksanakan tugas tertentu yang diberikan atasan.

Surat Perintah berisi macam-macam,sesuai dengan tugas atau perintah apa yang telah dimandatkan oleh pemberi tugas. Sebagai salah satu surat resmi, surat perintah wajib mencantumkan Kop Surat dari instansi atau perusahaan pembuat surat dengan alamat yang lengkap. Surat Perintah Kerja (SPK) perlu dibuat karena tidak lain bahwa ada kalanya suatu pekerjaan harus dikerjakan oleh orang-orang tertentu yang benar-benar berpengalaman dalam bidangnya dan memiliki otoritas dan kewenangan untuk melakukan pekerjaan tersebut sesuai dengan kemampuan yang dipercayakan kepadanya. Maka dengan demikian Surat Perintah Kerja (SPK) dibuat oleh perusahaan/pemberi kerja yang memiliki tujuan untuk memberikan suatu kententuan pengerjaan pekerja yang sesuai dengan bidangnya. kuasa pengguna anggaran atau pejabat pembuat komitmen dibantu ULP atau pejabat pengadaan barang dan jasa menyusun dan menerbitkan Surat Perintah Kerja, dengan ketentuan untuk pengadaan barang atau pekerjaan konstruksi atau jasa lainnya dengan nilai sampai dengan Rp100.000.000.- (dalam draft perubahan Perpres Nomor 16 Tahun 2018 nilainya adalah sampai dengan RP200.000.000) dan untuk Jasa Konsultasi

\footnotetext{
${ }^{17}$ Www.konsultasi-hukum-online.com diakses pada tanggal 18 September 2018, pukul 15.36 WIB.
} 
dengan nilai sampai dengan Rp50.000.000,- melalui Penerbitan Surat Perintah (SPK), sedangkan untuk pengadaan barang/Pekerjaan Konstruksi/jasa lainnya yang nilainya diatas Rp100.000.000,- (dalam draft perubahan Perpres Nomor 16 Tahun 2018 nilainya adalah diatas $\mathrm{Rp} 200.000 .000$ ) dan untuk pengadaan jasa konsultasi yang nilainya diatas Rp50.000.000.- dilakukan dengan penerbitan Surat Perjanjian.

Surat Perintah Kerja lebih sederhana dibanding dengan surat perjanjian, namun tetap ditandatangani oleh kedua belah pihak baik oleh Penyedia Barang/ Jasa maupun KPA/PPK dan sekurang - kurang memuat: ${ }^{18}$

1. Judul SPK;

2. Nomor dan tanggal SPK;

3. Nomor dan tanggal Surat Permintaan Penawaran;

4. Nomor dan tanggal Berita Acara Hasil Negosiasi;

5. Sumber dana;

6. Waktu pelaksanaan;

7. Uraian pekerjaan yang dilaksanakan;

8. Nilai pekerjaan;

9. Tata cara pembayaran;

10. Sanksi;

11. Tanda tangan kedua belah pihak;

12. Standar ketentuan dan syarat umum SPK

\section{Perjanjian atau Kontrak}

Perjanjian atau kontrak di jelaskan di dalam Pasal 1313 BW yaitu suatu peristiwa dimana seorang atau satu pihak berjanji kepada seorang atau pihak lain atau dimana dua orang atau dua pihak itu saling berjanji untuk melaksanakan suatu hal. Di dalam perjanjian terdapat beberapa jenis yaitu antara lain :

A. Berdasarkan Bentuk Imbalan

1. Lump sum

2. Harga satuan

3. Gabungan Lump sum dan harga satuan

4. Kontrak Persentase

5. Terima jadi

\footnotetext{
${ }^{18} \mathrm{Http}$ ://id.ahmad.wikia.com/wiki/pengadaan_barang/Jasa_Pemerintah/Penerbitan_Surat_Perintah_Kerja_dan_Kontrak/Surat_Perjanjian diakses pada tanggal 17 September 2018, pukul 13.21 WIB.
} 
B. Berdasarkan Jangka Waktu

Tahun Tunggal Kontrak pelaksanaan pekerjaan yang mengikat dana anggaran untuk masa 1 tahun anggaran:

1. Tahun Jamak

Adalah kontrak pelaksanaan pekerjaan yang mengikat dana anggaran untuk masa lebih dari 1 tahun anggaran yang dilakukan atas persetujuan Menteri Keuangan untuk pengadaan yang dibiayai dari APBN dan bernilai diatas Rp 10.000.000.000,-, persetujuan Menteri/Pimpinan Lembaga yang bersangkutan untuk pengadaan yang dibiayai dari APBN dan bernilai sampai dengan Rp 10.000.000.000,-, dan persetujuan Gubernur/Bupati/ Walikota untuk yang dananya dibiayai dari APBD.

Berdasarkan draft perubahan Perpres Nomor 16 Tahun 2018 Tentang Pengadaan Barang dan Jasa, ketentuan mengenai kontrak tahun jamak adalah sebagai berikut:

1. Menteri/Pimpinan Lembaga yang bersangkutan untuk kegiatan yang nilai kontraknya sampai dengan Rp 10.000.000.000,00 (sepuluh miliar rupiah) bagi kegiatan: penanaman benih/bibit, penghijauan, pelayanan perintis laut/udara, makanan dan obat di rumah sakit, makanan untuk narapidana di Lembaga Pemasyarakatan, pengadaan pita cukai, layanan pembuangan sampah dan pengadaan jasa cleaning service.

2. Menteri Keuangan untuk kegiatan yang nilainya diatas Rp10.000.000.000,00 (sepuluh miliar rupiah) dan kegiatan yang nilainya sampai dengan Rp 10.000.000.000,00 (sepuluh miliar rupiah) yang tidak termasuk dalam kriteria pada huruf a diatas. Persetujuan oleh Menteri Keuangan diselesaikan paling lambat 7 (tujuh) hari kerja sejak dokumen diterima secara lengkap.

3. Kontrak Tahun Jamak pada pemerintah daerah disetujui oleh Kepala Daerah seusai dengan ketentuan peraturan perundang - undangan.

C. Berdasarkan Jumlah Pengguna Barang/Jasa

1. Kontrak Pengadaan Tunggal;

2. Kontrak Pengadaan Bersama;

3. Kontrak Payung (Framework Contract). 
Berdasarkan Perpres Nomor 54 Tahun 2010, menetapkan isi yang terdapat di dalam kontrak minimal memuat ketentuan :

1. Pokok Perjanjian, yang meliputi :

a. Pembukaan, memuat tentang :

1. Judul Kontrak;

2. Nomor Kontrak, apabila Kontrak berupa perubahan Kontrak maka nomor Kontrak harus berurut sesuai dengan berapa kali mengalami perubahan;

3. Tanggal Kontrak;

4. Kalimat Pembuka, menjelaskan bahwa para pihak pada hari, tanggal, bulan dan membuat dan menandatangani kontrak;

5. Para pihak dalam Kontrak meliputi nama, jabatan dan alamat serta kedudukan para pihak dalam kontrak tersebut, apakah sebagai pihak pertama atau kedua;

6. Latarbelakang, menjelaskanlatarbelakang ditandatanganinya kontrak yang meliputi informasi.

b. Isi, sedikitnya memuat :

1. Pernyataan bahwa para pihak telah sepakat atau setuju untuk mengadakan kontrak mengenai obyek yang dikontrakkan sesuai dengan jenis pekerjaannya.

2. Pernyataan bahwa para pihak telah menyetujui besarnya harga kontrak. Harga kontrak harus ditulis dengan angka dan huruf, serta rincian sumber pembiayaannya.

3. Pernyataan bahwa ungkapan - ungkapan dalam perjanjian harus mempunyai arti dan makna yang sama seperti yang tercantum dalam kontrak.

4. Pernyataan bahwa kontrak dibuat ini meliputi beberapa dokumen dan merupakan satu kesatuan yang disebut kontrak.

5. Pernyataan bahwa apabila terjadi pertentangan antara ketentuan yang ada dalam dokumen - dokumen kontrak maka yang dipakai adalah dokumen yang urutannya lebih dulu sesuai dengan hirarkinya.

6. Pernyataan mengenai persetujuan para pihak untuk melaksanakan kewajiban masing - masing, yaitu pihak pertama membayar harga yang tercantum dalam Kontrak dan pihak kedua melaksanakan pekerjaan yang diperjanjikan dalam kontrak.

7. Pernyataan mengenai jangka waktu pelaksanaan pekerjaan, yaitu kapan dimulai dan diakhirinya pekerjaan tersebut.

8. Pernyataan mengenai kapan mulai efektif berlakunya kontrak. 
c. Penutup

1. Pernyataan bahwa para pihak dalam perjanjian ini telah menyetujui untuk melaksanakan perjanjian sesuai ketentuan peraturan perundang - undangan di Indonesia.

2. Tanda tangan para pihak dalam surat perjanjian dengan dibubuhi materai.

3. Kontrak ditandatangani setelah ada penunjukkan penyedia. Oleh karena itu, tanggal penandatanganan kontrak tidak boleh mendahului tanggal SPPBJ.

\section{Objek Surat Perintah Kerja}

Dalam Surat Perintah Kerja (SPK) terdapat suatu pengikatan antara pihak pengguna jasa dengan pihak penyedia jasa yang mana pada saat melakukan perjanjian dan kontrak kerja yang akan dilakukan oleh pihak penyedia jasa ddalam proyek yang telah di perjanjikan dan nilai anggaran yang sudah di tentukan, maka Surat Perintah Kerja diturunkan oleh pihak pengguna jasa sebagai Jaminan yang dipergunakan untuk pengkreditan dana yang dipergunakan untuk pihak penyedia jasa. Pada nilai jaminan yang di tentukan dalam suatu suatu surat SPK tersebut memiliki nilai sesuai dengan ketentuan Perpres Nomor 16 Tahun 2018 tentang Penggadaan Barang dan Jasa.

Dengan demikian, Surat Perintah Kerja (SPK) merupakan suatu jaminan yang dapat dipergunakan oleh pihak penyedia jasa sebagai objek jaminan yang dapat dijaminkan kepada bank, karena didalam SPK tersebut terdapat Nilai materiel yang pasti ada karena dalam SPK tersebut terkandung besarnya anggaran yang akan diperoleh saat menyelesaikan proyek tersebut. Pada Undang - undang Nomor 7 Tahun 1992 sebagaimana telah diubah dengan Undang - undang Nomor 10 Tahun 1998 tentang Perbankan. Pada dasarnya SPK bukan merupakan surat berharga, tetapi dapat dijadikan objek jaminan pada bank karena memenuhi syarat benda sebagai objek jaminan kredit, yaitu didalam SPK terkandung suatu nilai ekonomis dan dapat dialihkan. 


\section{Perlindungan Bank Sebagai Penerima Jaminan Surat Perintah Kerja Dalam Kontrak Pengadaan Barang dan jasa}

\section{Kedudukan Bank sebagai Penerima Jaminan dalam Pengadaan Barang/Jasa}

Kredit merupakan tulang punggung bagi pembangungan di bidang ekonomi. ${ }^{19}$ Oleh karena itu, perkreditan mempunyai arti yang penting dalam berbagai aspek pembangunan seperti : bidang perdagangan, perindustrian, perumahan, transportasi dll. Sektor perkreditan sarana modal bagi masyarakat bisnis, bagi pengusaha mengambil kredit merupakan factor yang tidak dapat dipisahkan dari kehidupan bisnis. Namun bagi perbankan setiap pemberian kredit yang disalurkan kepada pengusaha selalu mengandung risiko. Oleh karena itu, perlu unsur pengamanan dalam pengembaliannya. Unsur pengamanan (safety) merupakan salah satu prinsip dasar dalam peminjaman kredit selain unsur keserasiannya (suitability) dan keuntungan (profitability). ${ }^{20}$ Bentuk pengamanan kredit dalam praktik perbankan dilakukan dalam pengikatan jaminan.

Keberadaan jaminan kredit merupakan upaya guna memperkecil risiko, dimana jaminan merupakan sarana perlindungan bagi keamanan debitur yaitu kepastian hukum akan pelunasan utang debitur atau pelaksanaan prestasi oleh debitur atau penjamin debitur. ${ }^{21}$ Pemberian jaminan kebendaan selalu menyendirikan suatu bagian dari kekayaan seseorang (si pemberi jaminan) dan menyediakan guna pemenuhan kewajiban (pembayaran hutang) seorang debitur, sedangkan jaminan perorangan merupakan suatu perjanjian antara si pemberi piutang (kreditur) dengan orang ketiga yang menjamin dipenuhinya kewajiban - kewajiban si berhutang (debitur). ${ }^{22}$ Menurut ketentuan Undang - undang, para kreditur mempunyai hak jaminan terhadap pemenuhan suatu hutang terhadap seluruh harta kekayaan debitur

${ }^{19}$ Tan Kamelo, Hukum Jaminan Fidusia Suatu Kebutuhan yang Didambakan, Alumni, Bandung, 2004.[1].

${ }^{20}$ Muchdarsya Sinungun, Dasar - Dasar dan Teknik Manajemen Kredit, Bina Aksara, Jakarta, 1999.[4].

${ }^{21}$ Djuhaendah Hasan, Lembaga Jaminan Kebendaan Bagi Tanah dan Benda Lain yang Melekat pada Tanah dalam Konsep Penerapan Asas Pemisahan Horizontal, Citra Aditya Bakti, Bandung, 1996.[23].

${ }^{22}$ R. Subekti, Jaminan - Jaminan untuk Pemberian Kredit Menurut Hukum Indonesia (Termasuk Hak Tanggungan), Citra Aditya Bakti, Bandung, 1991.[15]. 
baik yang berwujud bunga bergerak maupun tidak bergerak, baik benda - benda yang telah ada maupun yang akan ada. Menurut Pasal 1132 BW jika hasil penjualan benda - benda tersebut tidak memenuhi pembayaran piutang para kreditur, maka hasil antara para kreditur seimbang dengan piutangnya masing - masing. Hak pemenuhan dari para kreditur yang demikian itu adalah sama dan satu dengan yang lainnya. Kreditur tersebut dikenal dengan sebutan kreditur konkuren atau unsecuredcreditors. $^{23}$

Jaminan Fidusia adalah salah satu sarana perlindungan hukum bagi keamanan bank yaitu sebagai kepastian bahwa debitur akan melunasi kreditnya dan mengantisipasi adanya itikad buruk debitur maka benda objek jaminan fidusia tersebut telah dilakukan pendaftaran di Kantor Pendaftaran Fidusia, sehingga penerima jaminan fidusia telah mendapatkan hak sebagai kreditur preferen yaitu hak mengambil pelunasan piutangnya atas hasil eksekusi benda yang menjadi objek jaminan fidusia mendahului kreditur - kreditur lainnya, bahkan sekalipun pemberi fidusia dinyatakan pailit atau dilikuidasi karena hak yang didahulukan dari penerima fidusia tidak hapus karena benda yang menjadi objek jaminan fidusia tidak termasuk dalam harta pailit pemberi fidusia.

Kreditur pemegang jaminan memiliki hak untuk mengeksekusi barang jaminan untuk dijual secara lelang guna pembayaran utang debitur, jika debitur lalai melaksanakan kewajibannya berdasarkan perjanjian kredit atau biasa disebut dengan wanprestasi. Pemberian hak kepada kreditur untuk mengeksekusi jaminan kebendaan yang diberikan oleh debitur dijelaskan di dalam peraturan perundangundangan berikut ini:

1. Pasal $1155 \mathrm{BW}$;

2. Pasal 15 ayat (3) jo. Pasal 29 Undang-Undang No. 42 Tahun 1999 tentang Jaminan Fidusia;

3. Pasal 6 jo. Pasal 20 Undang-Undang No. 4 Tahun 1996 tentang Hak Tanggungan Atas Tanah Beserta Benda-Benda Yang Berkaitan Dengan Tanah.

\footnotetext{
${ }^{23}$ Ibid.[80].
} 
Pada Pasal 21 Undang-Undang Jaminan Fidusia, yang dimaksud dengan "cidera janji" (wanprestasi) adalah tidak memenuhi prestasi, baik yang berdasarkan perjanjian pokok, perjanjian jaminan fidusia, maupun perjanjian jaminan lainnya. Terdapat 3 macam bentuk prestasi berdasarkan Pasal 1234 BW, yaitu :

1. Untuk memberikan sesuatu;

2. Untuk berbuat sesuatu;

3. Untuk tidak berbuat sesuatu.

Berdasarkan bentuk-bentuk prestasi pada Pasal 1234 BW, wujud wanprestasi bisa berupa :

1. Debitur sama sekali tidak berprestasi;

2. Debitur keliru berprestasi;

3. Debitur terlambat berprestasi.

Apabila kredit macet terjadi karena debitur tidak melaksanakan prestasinya, sebagaimana terdapat dalam perjanjian kredit, maka sebelum melakukan eksekusi objek jaminan yang diberikan oleh debitur.

Pada dasarnya SPK bukan merupakan surat berharga, tetapi dapat dijadikan jaminan pada bank karena di dalam SPK terkandung suatu nilai ekonomis dan dapat dipindahtangankan. Bilamana bank mengalami kredit bermasalah bahkan sampai macet dalam pemberian kredit dengan jaminan berupa SPK, maka bank dapat melakukan upaya restrukturisasi kredit terlebih dahulu sebagaimana diatur pada Peraturan Bank Indonesia Nomor 14/15/PBI/2012 tentang Penilaian Kualitas Aset Bank Umum, Pasal 1. 26 yang dimaksud Restrukturisasi Kredit adalah upaya perbaikan yang dilakukan Bank dalam kegiatan perkreditan terhadap debitur yang mengalami kesulitan untuk memenuhi kewajibannya, yang dilakukan antara lain melalui:

a. penurunan suku bunga Kredit;

b. perpanjangan jangka waktu Kredit;

c. pengurangan tunggakan bunga Kredit;

d. pengurangan tunggakan pokok Kredit;

e. penambahan fasilitas Kredit; dan/atau

f. konversi Kredit menjadi Penyertaan Modal Sementara.

Bank hanya dapat melakukan Restrukturisasi Kredit terhadap debitur yang memenuhi kriteria sebagai berikut: 
a. debitur mengalami kesulitan pembayaran pokok dan/atau bunga Kredit; dan

b. debitur masih memiliki prospek usaha yang baik dan dinilai mampu memenuhi kewajiban setelah Kredit direstrukturisasi.

Sedangkan penyelesaian melalui jalur hukum antara lain :

1. Melalui panitia urusan piutang negara;

2. Melalui badan peradilan;

3. Melalui arbitrase atau badan alternative penyelesaian sengketa.

Berdasarkan Pasal 7 UUJF menjelaskan bahwa Utang yang pelunasannya dijamin dengan fidusia dapat berupa:

a. Utang yang telah ada;

b. Utang yang akan timbul dikemudian hari yang telah diperjanjikan dalam jumlah tertentu; atau

c. Utang yang pada saat eksekusi dapat ditentukan jumlahnya berdasarkan perjanjian pokok yang menimbulkan kewajiban memenuhi suatu prestasi.

Penyelesaian kredit bermasalah umumnya ditempuh dengan 2 (dua) cara yakni penyelamatan kredit dan penyelesaian kredit. Penyelamatan kredit yang dimaksud adalah suatu langkah penyelesaian kredit bermasalah melalui perundingan kembali antara bank sebagai kreditur dan nasabah peminjam sebagai debitur, sedangkan penyelesaian kredit adalah suatu langkah penyelesaian kredit bermasalah melalui lembaga hukum.

Definisi cessie di Indonesia menurut Subekti adalah "suatu cara pemindahan piutang atas nama dimana piutang itu dijual oleh kreditur lama kepada orang yang nantinya menjadi kreditur baru, namun hubungan hukum utang piutang tersebut tidak hapus sedetikpun, tetapi dalam keseluruhannya dipindahkan kepada kreditur baru". ${ }^{24}$ Cessie adalah cara pengalihan dan atau penyerahan piutang atas nama sebagaimana yang dimaksud di dalam Pasal 613 Kitab Undang-Undang Hukum Perdata (KUHPerdata). ${ }^{25}$ Penyerahan tiap-tiap piutang karena surat bawa dilakukan

${ }^{24}$ Subekti, Hukum Perjanjian, Intermasa, Jakarta, 1998.[71] (selanjutnya disebut Subekti I)

${ }_{25}$ Soeharnoko dan Endah Hartati, Doktrin Subrogasi, Novasi dan Cessie, Kencana, Jakarta, 2008.[101]. 
dengan penyerahan surat itu; penyerahan tiap-tiap piutang karena surat ditunjuk dilakukan dengan penyerahan surat disertai dengan endosemen”. Unsur-unsur yang dapat disimpulkan berdasarkan Pasal 613 KUHPerdata tersebut dalam suatu tindakan cessie, yakni:

1. Dibuatkan akta otentik atau akta di bawah tangan.

2. Hak-hak yang melekat pada piutang atas nama dialihkan/berpindah kepada pihak penerima pengalihan.

3. Cessie hanya berakibat hukum kepada debitur jika telah diberitahukan kepadanya atau secara tertulis disetujui dan diakuinya.

Dalam cessie, Pihak yang mengalihkan atau menyerahkan disebut Cedent, sedangkan pihak yang menerima pengalihan atau penyerahan disebut Cessionaris, lalu debitur dari tagihan yang dialihkan atau diserahkan disebut Cessus. ${ }^{26}$ Penyerahan utang piutang atas nama dan kebendaan tak bertubuh lainnya, dilakukan dengan jalan sebuah akta otentik atau di bawah tangan, dengan mana hakhak atas kebendaan itu dilimpahkan kepada orang lain. Oleh karena itu, cessie harus tertulis. Penyerahan yang demikian bagi si berutang tidak ada akibatnya, melainkan setelah penyerahan itu diberitahukan kepadanya, atau secara tertulis disetujui dan diakuinya. Cessionaris bisa menyatakan menerima cessie dalam suatu akta/surat tersendiri dan secara tertulis. ${ }^{27}$

Dengan adanya, penyerahan piutang secara cessie maka pihak ketiga menjadi kreditur yang baru yang menggantikan kreditur yang lama yang diikuti pula dengan beralihnya seluruh hak dan kewajiban kreditur lama terhadap debitur kepada pihak ketiga selaku kreditur baru. Hubungan hukum antara debitur dan kreditur berdasarkan perjanjian kredit yang telah ada sebelumnya tidak menjadi putus, sehingga tidak terjadi hubungan hukum yang baru yang menggantikan hubungan hukum yang lama. Dengan demikian yang terjadi adalah pengalihan seluruh hak

${ }^{26}$ Herlien Budiono, Ajaran Umum Hukum Perjanjian dan Penerapannya di Bidang Kenotariatan, Citra Aditya, Bandung, 2010.[185].

${ }^{27}$ Rachmad Setiawan dan J. Satrio, Penjelasan Hukum tentang Cessie, Gramedia, Jakarta, 2010.[47]. 
dan kewajiban kreditur berdasarkan perjanjian kredit yang ada kepada pihak ketiga yang selanjutnya menjadi kreditur baru. ${ }^{28}$ Dengan adanya cessie, akibat hukum yang terpenting adalah sebagai berikut:

1. Piutang beralih dari cedent ke cessionaris.

2. Setelah terjadinya cessie, kedudukan cessionaris menggantikan kedudukan cedent, yang berarti segala hak yang dimiliki oleh cedent terhadap cessus dapat digunakan oleh cessionaris sepenuhnya. ${ }^{29}$

\section{Prosedur Penilaian Surat Perintah Kerja Sebagai Jaminan}

Berdasarkan pengertian Surat Perintah Kerja adalah surat yang diberikan oleh Kuasa Pengguna Anggaran atau Pejabat Pembuat Komitmen dibantu ULP/ Pejabat Pengadaan Barang/jasa menyusun/menerbitkan Surat Perintah Kerja (SPK) dan Surat Perjanjian agar melaksanakan tugas tertentu yang telah di tentukan. Maka dalam hal perwujudan Surat Perintah Kerja ini sangat penting untuk digunakan bagi para penyedia jasa tentunya dibidang Barang/Jasa/Konstruksi/Konsulta yang dimana dalam proses pemaparan kerjanya dapat dilaksanakan apabila terdapat Surat Perintah Kerja yang dapat dijaminkan atas suatu dana yang dipergunakan dalam proses perwujudan suatu proyek yang telah ditentukan.

Sebelum terwujudnya Surat Perintah Kerja (SPK) terdapat konrak yang telah disepakati antar para pihak dengan memberikan nilai proyek yang dikeluarkan dalam proses perwujudtan konstruksi, dan kontrak tersebut dapat dibuat setelah ditentukannya pemenang tender dalam suatu proyek tersebut. Maka dengan demikian Surat Perintah Kerja dapat dibuat.

Melihat dari proses untuk mendapatkan Surat Perintah Kerja (SPK) melalui proses kesepakatan kontrak kedua belah pihak maka pemenang tender harus sepakat dengan kontrak yang telah ditentukan oleh pemerintah atas proyek yang telah di adakan. Kontrak itu sendiri merupakan suatu persetujuan antara dua orang atau lebih yang menimbulkan kewajiban untuk melakukan atau tidak melakukan tindakan

\footnotetext{
28 Ibid.[21].

29 Ibid.[56].
} 
secara sebagian. Kontrak dilakukan oleh pihak-pihak yang berkompeten dalam kesepakatan yang saling menguntungkan. Kontrak tertuang di dalam dokumen tertulis yang berisi persetujuan dari para pihak, dengan syarat dan ketentuan sebagai bukti dari segala kewajiban.

Dengan demikian, kontrak lebih spesifik berdasarkan ketentuan Perlem LKPP No. 9 Tahun 2018 yang merupakan aturan turunan dari Perpres 16/2018 menjelaskan bahaw PPK memilih jenis Kontrak Pengadaan Barang/Jasa dengan mempertimbangkan antara lain; jenis barang/jasa, spesifikasi teknis/KAK, volume, lama waktu pekerjaan, dan/atau kesulitan dan risiko pekerjaan. Dalam modul Tingkat Menengah yang dikeluarkan LKPP menyebutkan bahwa prakteknya tidak dibedakan antara kontrak (contract) dan nama lainnya. Nama lain dari kontrak (contract) adalah:

1. Perjanjian (Agreement)

2. Nota Kesepakatan (Memorandum of Agreement)

3. Nota Kesepahaman (Memorandum of Understanding)

4. Surat Pernyataan Keinginan (Letter of Intent)

5. Treaty

6. Convenant

7. Accord

Berdasarkan keterangan ini dapat disimpulkan bahwa bentuk lain dari kontrak dalam pengadaan barang/jasa adalah Dokumen Pengadaan. Sesuai dengan Pasal 1 ayat (21) disebutkan Dokumen Pengadaan adalah dokumen yang ditetapkan oleh ULP/Pejabat Pengadaan yang memuat informasi dan ketentuan yang harus ditaati oleh para pihak dalam proses Pengadaan Barang/Jasa.

\section{Jenis-jenis Kontrak Pengadaan Barang/Jasa Pemerintah dalam Perpres \\ 16/2018 dan Aturan Turunannya}

Jenis-jenis kontrak dalam PBJ sesuai dengan Perpres No. 16 Tahun 2018 akan lebih sederhana. Jenis kontrak akan disederhanakan menjadi tiga jenis pengaturan saja, yaitu sebagai berikut. Untuk pekerjaan barang/konstruksi/jasa lainnya hanya akan diatur kontrak lumpsum, harga satuan, gabungan, terima jadi (turnkey) dan kontrak payung. Jenis Kontrak untuk Pengadaan Barang/Pekerjaan Konstruksi/Jasa 
Lainnya terdiri dari:

1. Lumsum

Kontrak Lumsum digunakan dalam hal ruang lingkup, waktu pelaksanaan, dan produk/keluaran dapat didefinisikan dengan jelas. Kontrak Lumsum digunakan misalnya:

a. Pelaksanaan Pekerjaan Kontruksi Sederhana;

b. Pekerjaan Konstruksi Terintegrasi (design and build)

c. Pengadaan Peralatan Kantor;

d. Pengadaan Benih;

e. Pengadaan Jasa Boga;

f. Sewa Gedung; atau

g. Pembuatan Video Grafis.

Pembayaran dalam Kontrak Lumsum dengan harga pasti dan tetap, senilai dengan harga yang dicantumkan dalam Kontrak. Pembayaran dapat dilakukan sekaligus berdasarkan hasil/keluaran atau pembayaran secara bertahap pekerjaan berdasarkan tahapan atau bagian keluaran yang dilaksanakan.

2. Harga Satuan

Kontrak Harga Satuan digunakan dalam hal ruang lingkup, kuantitas/volume tidak dapat ditetapkan secara tepat yang disebabkan oleh sifat/karakteristik, kesulitan dan resiko pekerjaan. Dalam Kontrak Harga Satuan pembayaran dilakukan berdasarkan harga satuan yang tetap untuk masing-masing volume pekerjaan dan total pembayaran (final price) tergantung kepada total kuantitas/volume dari hasil pekerjaan. Pembayaran dilakukan berdasarkan pengukuran hasil pekerjaan yang dituangkan dalam sertifikat hasil pengukuran (contoh monthly certificate). Kontrak Harga Satuan digunakan misalnya untuk kegiatan pembangunan gedung atau infrastruktur, pengadaan jasa boga pasien di Rumah Sakit.

3. Gabungan Lumsum dan Harga Satuan

Kontrak Gabungan Lumsum dan Harga Satuan digunakan dalam hal terdapat bagian pekerjaan yang dapat dikontrakkan menggunakan Kontrak Lumsum dan terdapat bagian pekerjaan yang dikontrakkan menggunakan Kontrak Harga Satuan. Kontrak Gabungan Lumsum dan Harga Satuan digunakan misalnya untuk Pekerjaan Konstruksi yang terdiri dari pekerjaan pondasi tiang pancang 
dan bangunan atas.

4. Terima Jadi (Turnkey)

Kontrak Terima Jadi digunakan dalam hal Kontrak Pengadaan Pekerjaan Konstruksi atas penyelesaian seluruh pekerjaan dalam batas waktu tertentu dengan ketentuan sebagai berikut:

a. Jumlah harga pasti dan tetap sampai seluruh pekerjaan selesai dilaksanakan; dan

b. Pembayaran dapat dilakukan berdasarkan termin sesuai kesepakatan dalam kontrak.

Penyelesaian pekerjaan sampai dengan siap dioperasonalkan/difungsikan sesuai kinerja yang telah ditetapkan. Kontrak Terima Jadi biasa digunakan dalam Pekerjaan Konstruksi terintegrasi, misalnya Enginnering Procurement Construction (EPC) pembangunan pembangkit tenaga listrik, pabrik, dan lainlain.

5. Kontrak Payung

Kontrak payung digunakan dalam hal pekerjaan yang akan dilaksanakan secara berulang dengan spesifikasi yang pasti namun volume dan waktu pesanan belum dapat ditentukan. Kontrak Payung digunakan misalnya pengadaan obat tertentu pada rumah sakit, jasa boga, jasa pelayanan perjalanan (travel agent), atau pengadaan material. ${ }^{30}$

Berdasarkan macam-macam bentuk kontrak Konstruksi Pengadaan Barang/Jasa Pemerintah dalam Perpres 16/2018. Merupakan suatu tahapan sebagai syarat untuk terwujudnya Surat Perjanjian Kerja (SPK) yang akan dipergunakan sebagai jaminan.

\section{Surat Perintah Kerja (SPK) Memiliki Nilai Jaminan}

Berdasarkan kesepakatan kontrak yang telah dibuat antara Penyedia Jasa dan Pengguna Jasa untuk melakukan proyek konstruksi dengan ketentuan yang ada,

\footnotetext{
${ }^{30} \mathrm{http} / / /$ id.ahmad.wikia.com/wiki/Pengadaan_Barang/Jasa_Pemerintah/Penerbitan_Surat Perintah_Kerja_dan_Kontrak/Surat_Perjanjian, diakses pada tanggal 5 Oktober 2018 pukul 15.00 WIB
} 
maka dengan demikian berdasarkan hasil penetapan pemenang/keputusan pemenang lelang, Kuasa Pengguna Anggaran atau Pejabat Pembuat Komitmen dibantu ULP/ Pejabat Pengadaan Barang/jasa menyusun/menerbitkan Surat Perintah Kerja (SPK) dan Surat Perjanjian, dengan ketentuan untuk pengadaan Barang/Pekerjaan Konstruksi/Jasa Lainnya dengan nilai yang telah di tentukan Perpres Nomor 16 Tahun 2018 tentang Pengadaan Barang/Jasa dengan demikian Surat Perintah Kerja (SPK) yang telah dikeluarkan mengandung nilai materil yang telah di tentukan dari suatu kontrak konstruksi yang telah di sepakati tersebut. dan di dalam Surat Perintah Kerja itu terdapat suatu hak tagihan atas sejumlah uang yang pasti akan ada. Berdasarkan Ketentuan Perpres Nomor 16 Tahun 2018 Tentang Pengadaan Barang/Jasa.

\section{Kedudukan Surat Perintah Kerja Sebagai Objek Jaminan}

Surat Perintah Kerja (SPK) merupakan surat yang dipergunakan sebagai jaminan yang terdapat nilai suatu dana yang akan dipergunakan sebagai kebutuhan yang dibutuhkan oleh pihak penyedia jasa, dengan demikian Surat Perintah tersebut sangat penting untuk kelancaran suatu proyek agar berjalan sesuai dengan waktu yang telah ditentukan antara pihak pengguna jasa dan pihak penyedia jasa. Namun selain Surat Perintah Kerja (SPK) sebagai jaminan pokok yang akan dipergunakan terdapat juga kebijakan Bank yang akan dikeluarkan berupa jaminan tambahan yaitu jaminan yang setara dengan kontrak yang telah di perjanjikan dapat berupa jaminan berupa benda bergerak/tidak bergerak.

Berdasarkan kesepakatan kontrak yang telah dibuat antara Penyedia Jasa dan Pengguna Jasa untuk melakukan proyek konstruksi dengan ketentuan yang ada, maka dengan demikian berdasarkan hasil penetapan pemenang/keputusan pemenang lelang, Kuasa Pengguna Anggaran atau Pejabat Pembuat Komitmen dibantu ULP/ Pejabat Pengadaan Barang/jasa menyusun/menerbitkan Surat Perintah Kerja (SPK) dan Surat Perjanjian, dengan ketentuan untuk pengadaan Barang/Pekerjaan Konstruksi/Jasa Lainnya dengan nilai yang telah di tentukan Perpres Nomor 16 Tahun 2018 tentang Pengadaan Barang/Jasa dengan demikian Surat Perintah Kerja (SPK) yang telah dikeluarkan mengandung nilai materil yang telah di tentukan dari 
suatu kontrak konstruksi yang telah di sepakati tersebut. dandi dalam Surat Perintah Kerja itu terdapat suatu hak tagihan atas sejumlah uang yang pasti akan ada. Melihat dari perpres Nomor 16 Tahun 2018 Pasal 28 tentang Pengadaan Barang dan Jasa.

\section{Kesimpulan}

1. Dalam hal pemberian kredit, bank mensyaratkan adanya suatu jaminan. Jaminan tersebut bertujuan untuk memberikan rasa aman pada bank. Salah satu objek yang dapat dijadikan jaminan di Indonesia adalah Surat Perintah Kerja (SPK). Surat Perintah Kerja (SPK) merupakan bagian kecil dari kontrak kerja dimana SPK mempunyai kesamaan dengan kontrak kerja yaitu untuk menunjukkan adanya hubungan antara pihak pengguna dan penyedia jasa. Jaminan yang berupa SPK atau kontrak kerja dapat dijadikan objek jaminan karena mempunyai nilai ekonomis dan dapat dipindah tangakan. SPK atau kontrak kerja yang dibebani lembaga jaminan fidusia akan melahirkan hak kebendaan. Pemberian kredit dengan jaminan berupa SPK tidak hanya berupa tagihan proyek yang lahir dari SPK saja tetapi juga terdapat jaminan tambahan lainnya berupa barang tidak bergerak, barang bergerak, deposito/giro/ tabungan yang diblokir dan surat berharga.

2. Perlindungan hukum bagi bank yang memberikan kredit kepada pihak pemenang tender bahwa dana tersebut oleh Penyedia jasa selaku pemenang tender tersebut dipergunakan untuk keberlangsungan kelancaran suatu proyek kontruksi yang telah di perjanjikan dalam suatu kontrak pada masa pelelangan tersebut. Bank memberikan suatu dana kepada pihak penyedia jasa dengan jaminan yaitu Surat Perintah Kerja (SPK) yang diikuti dengan adanya cessi, didalam surat perintah tersebut telah berisikan dana yang akan ada dengan nilai dana kontrak yang telah di perjanjikan pada saat sebelum di turunkannya Surat Perintah Kerja (SPK) tersebut. Bilamana nasabah wanprestasi dan menimbulkan kredit bermasalah maka upaya yang dapat dilakukan oleh bank dengan restrukturisasi kredit terlebih dahulu apabila tidak berhasil maka objek jaminan tersebut dapat dieksekusi sebagai pelunasan kreditnya. 


\section{Daftar Bacaan}

\section{Buku}

Badrulzaman, Mariam Darus, Kompilasi Hukum Perikatan, Citra Aditya Bakti, Bandung, 2001.

Budiono, Herlien, Ajaran Umum Hukum Perjanjian dan Penerapannya di Bidang Kenotariatan, Citra Aditya, Bandung: Citra Aditya, 2010.

Gunawan Widjadja, Ahmad Yani, Jaminan Fidusia, Raja Grafindo Persada, 2001. Hansen, Seng, Manajemen Kontrak Konstruksi, Kompas Gramedia, 2016.

Hasan, Djuhaendah, Lembaga Jaminan Kebendaan Bagi Tanah dan Benda Lain yang Melekat pada Tanah dalam Konsep Penerapan Asas Pemisahan Horizontal, Citra Aditya Bakti, Bandung, 1996.

Hermansyah, Hukum Perbankan Nasional Indonesia, Kencana, Jakarta, 2006.

Kamelo, Tan, Hukum Jaminan Fidusia Suatu Kebutuhan yang Didambakan, Alumni, Bandung, 2004.

Marzuki, Peter Mahmud, Penelitian Hukum, Kencana, Jakarta, 2010.

Masjchoen, Sri Soedewi, Hukum Bangunan Perjanjian Pemborongan Bangunan, Liberty, Jogjakarta, 2003.

Rachmad Setiawan dan J. Satrio, Penjelasan Hukum tentang Cessie, Gramedia, Jakarta, 2010.

Satrio, J., Hukum Jaminan Hak Jaminan Kebendaan, Citra Aditya Bakti, Bandung, 2007.

Simamora, Y. Sogar, Hukum Kontrak : Kontrak Pengadaan Barang dan Jasa Pemerintah di Indonesia, Kantor Hukum WINS \& Partners-Laksbang Justitia Surabaya, Surabaya, 2012. Indonesia, Semiloka Pembaharuan Hukum Perdata Indonesia, Fakultas Hukum Universitas Airlangga, Surabaya, 2013.

Sinungun, Muchdarsya Sinungun, Dasar - Dasar dan Teknik Manajemen Kredit, Bina Aksara, Jakarta, 1999.

Soeharnoko dan Endah Hartati, Doktrin Subrogasi, Novasi dan Cessie, Kencana, Jakarta: Kencana, 2008. 
Subekti, R., Jaminan - Jaminan untuk Pemberian Kredit Menurut Hukum Indonesia (Termasuk Hak Tanggungan), Citra Aditya Bakti, Bandung, 1991.

Subekti, Hukum Perjanjian, Intermasa, Jakarta, 1998.

Sutarno, Aspek-aspek Hukum Perkreditan pada Bank, Alfabeta, Bandung, 2005.

Trisadini Prasastinah Usanti dan Leonora Bakarbessy, Buku Referensi Hukum Perbankan Hukum Jaminan, Revka Petra Media, Surabaya, 2013.

\section{Jurnal}

Hadihardaja, Joetata, Membangun Industri Konstruksi Indonesia Menjadi Kelas Dunia, ejournal.undip.ac.id, Vol 13, No.2, 2005.

\section{Karya Ilmiah}

Eventia, Reifon Cristabella, Prinsip Hukum Dalam Pembentukan dan Pelaksanaan Kontrak Bangun Guna Serah (Build, Operate, Transfer/BOT), Disertasi, Fakultas Hukum Universitas Airlangga, Surabaya, 2016.

\section{Laman}

https://economy.okezone.com/read/2018/04/13/320/1886166/infrastrukturindonesia-di-peringkat-52-dunia-apa-masalahnya yang diakses pada tanggal 13 Mei 2017.

http://www.bankjatim.co.id/id/bisnis/pinjaman-1/kredit-modal-kerja, diakses pada tanggal 18 Agustus 2018 pukul 17.10 WIB.

www.konsultasi-hukum-online.com diakses pada tanggal 18 September 2018, pukul 15.36 WIB.

Http://id.ahmad.wikia.com/wiki/pengadaan_barang/Jasa_Pemerintah/Penerbitan Surat_Perintah_Kerja_dan_Kontrak/Surat_Perjanjian diakses pada tanggal 17 September 2018, pukul 13.21 WIB. 